This is a self-archived version of an original article. This version may differ from the original in pagination and typographic details.

Author(s): Aarto-Pesonen, Leena; Piirainen, Arja

Title: Teacher students' meaningful learning in widening learning worlds

Year: 2020

Version: Accepted version (Final draft)

Copyright: @ 2020 Informa UK Limited

Rights: In Copyright

Rights url: http://rightsstatements.org/page/InC/1.0/?language=en

Please cite the original version:

Aarto-Pesonen, L., \& Piirainen, A. (2020). Teacher students' meaningful learning in widening learning worlds. Teaching Education, 31(3), 323-342.

https://doi.org/10.1080/10476210.2018.1561662 


\title{
Teacher students' meaningful learning in widening learning worlds
}

Leena Aarto-Pesonen ${ }^{\mathrm{a}}$ and Arja Piirainen ${ }^{\mathrm{b}}$

${ }^{a}$ University of Jyväskylä, Department of Teacher Education, Finland

${ }^{b}$ University of Jyväskylä, Faculty of Sport and Health Sciences, Finland

Corresponding author:

Leena Aarto-Pesonen

University of Jyväskylä

Department of Teacher Education

PO Box 35

FI-40014 University of Jyväskylä

e-mail: leena.aarto-pesonen@jyu.fi

tel: +358408053941

ORCID iD: 0000-0001-6268-4506

\author{
Arja Piirainen \\ University of Jyväskylä \\ Faculty of Sport and Health Sciences \\ PO Box 35 \\ FI-40014 University of Jyväskylä \\ e-mail: arja.l.piirainen@jyu.fi \\ tel: +358408053585
}

ORCID iD: 0000-0003-4968-1276 


\section{Teacher students' meaningful learning in widening learning worlds}

This qualitative metasynthesis investigated students' meaningful learning experiences amid andragogical teacher education programmes. The programmes catered to the specific learning needs of adult students in the context of university-based teacher education. This study aimed to provide a wider picture of the frames of students' meaningful learning in andragogical teacher education programmes. The findings revealed three major learning worlds of adult students' meaningful learning, which formed a common system widening from the professional awakening to the transformative community and agency in society. Based on the findings, this study argues that in andragogical teacher education, which emphasises collaboration and networking in accordance with the current trend in higher education, teacher students may become empowered participants and active agents in society. The findings can be used in planning curricula, and developing programmes of higher education in general and teacher education in particular.

Keywords: teacher education, adult education, meaningful learning, frames of learning, andragogy, metasynthesis

\section{Introduction}

Education systems tend to face similar challenges in terms of teacher supply and demand. Most countries report challenges such as shortages of enrolment in initial teacher education, an ageing teacher population and teachers retiring or changing careers (e.g. Aragon, 2016; European Commission/EACEA/Eurydice, 2018, pp. 29-31). At the same time, the effectiveness of programs in producing high-quality teachers has become an issue of worldwide concern (e.g. American Psychological Association Taskforce, 2014; Sobolev, 2016; Teacher Education Ministerial Advisory Group, 2014). Therefore, institutions of higher education in general, and institutions of teacher education in particular, are looking for novel curriculum designs and pedagogical approaches to meet the foregoing challenges, and future challenges, such as increased learner diversity, differing expectations for teaching and learning (Andrade, 2016), and 
the need to adapt to rapid changes such as globalisation, digitalisation and multiculturalism.

To respond to the current needs and adapt to change, many institutions have turned to educational partnerships with employers, a range of hybrid or online delivery methods and more work-related and technology-enhanced learning (Andrade, 2016). A common focus in the development of current teacher education programmes is practical training (Cochran-Smith \& Power, 2010) and a need to increase collaboration and networking (American Psychological Association Taskforce, 2014; Green, 2016; Teacher Education Forum, 2016; Teacher Education Ministerial Advisory Group, 2014).

There is a wealth of existing research on the effects of change in traditional teacher education contexts (Afshan, 2016; Avalos, 2011; Broadbent \& Brady, 2013; Gossman \& Horder, 2016; Kehrwald \& McCallum, 2015; Korthagen, 2010; Korthagen, Loughran, \& Russell, 2006). Some of this research covers adult students' learning in the context of non-traditional teacher education programmes, in which collaboration and networking are emphasised (e.g. Rismiyanto \& Januarius, 2018) and which are created specifically for adult students (e.g. Aarto-Pesonen, 2013; Valli, Valli \& Lähdesmäki, 2017). However, there is little research on how teacher students experience new educational approaches (Kostiainen et al., 2018). More understanding is generally needed on how learners construe and construct their learning experiences (Billett, 2009, p. 33; Okukawa, 2008). In teacher education programmes, meaningful learning experiences are considered critical for ensuring students understand what is to be learned (Daves \& Roberts, 2010). As far as we know, there is still a lack of understanding of the meaningfulness of learning and especially the frames of adult students' meaningful learning in the context of andragogical teacher education. 
This study aims to provide a wider picture of teacher students' frames of meaningful learning in andragogical and university-based teacher education programmes. To investigate this issue, we made a systematic review using the Education Resources Information Center (ERIC) ProQuest database. Based on the findings, we provide practical contributions and new perspectives on the frames of meaningful learning in higher education focused on adult learners.

\section{Literature review}

\section{Meaningful learning}

Meaningful learning is generally described in terms of cognitive changes and development in the learners' cognitive structure (Ausubel \& Fitzgerald 1961; Novak 2002). Meaning construction involves the interpretation of new knowledge and experiences by connecting them with prior knowledge (Okukawa, 2008; Wolfe, 2006) and by giving the experiences coherence (Mezirow, 1991, p. 4). When learners' new knowledge does not fit the previous structures of her or his knowledge, meaningful learning is about to occur (Jarvis, 1987). Meaningful learning experiences tend to challenge former knowledge, allow new questions to arise, affect the learner personally and are subjectively valued by him or her (Merriam \& Clark, 1993). Eduart Lindeman, who came to be known as the 'father of adult education' (Rachal, 2015) and andragogy, underlines the emphatic importance of significant experiences in meaning-making processes. He states that adult education is actually a process through which learners become aware of their significant experiences. Meanings accompany experiences when learners know what is happening and especially, what importance the event carries for their personality (Lindeman 1926, p. 109). It is also noted that the student's construction 
of her or his identity as a teacher may be based on the teacher student's processes of meaning making in teacher education (Bruner, 1990; Okukawa, 2008, pp.49-50).

The concept of meaningful learning refers here to learning processes and the experiences of various activities, circumstances and events that adult students have considered to have a special meaning to them (Hakkarainen, Saarelainen \& Ruokamo, 2007, p. 89; Okukawa, 2008, p. 47). There is some research on meaningful learning experiences in the context of adult learning, non-formal education (e.g. Okukawa, 2008; Valli et al., 2017; Wolfe, 2006) and in various online and virtual learning environments (e.g. Hussain, 2013; Keskitalo, Pyykkö, \& Ruokamo, 2011; Tsai, Shen \& Chiang, 2013). We also know a little about meaning making processes and the identification of the characteristics of meaningful learning in initial teacher education (e.g. Kostiainen et al., 2018). However, in this study, we are especially interested in describing and providing a wider understanding of the frames of adult students' meaningful learning in andragogical teacher education.

\section{Learning in a social context}

Social theories of learning have emphasised the social context and the role of human interaction, collaborative learning (Vygotsky, 1934) and learning communities (Wenger, 1998). Knowles (1984) pointed out adults' need for learning. Adult students' need to know is mostly internal, and their self-concept leads towards the capability of self-direction. Earlier experiences prepare people for real-life situations (Knowles, 1984). Additionally, people learn with others in different environments (Bereiter, 2002; Lindeman, 1926). Hence, adult students' learning is closely connected to their lives and allows them to discover the meaning of their experiences (Lindeman, 1926). Education also has a non-vocational ideal when its purpose is to imbue life with meaning. Adult education concentrates on the situations, not the subjects, and places the highest value is 
the learner's own experience (Lindeman, 1926).

To learn as part of a learning community has also been a common andragogical principle, at least in the Nordic countries (Lindeman, 1926; Savicevic, 2008). Wenger (1998, p. 45) defined communities of practice as groups where the members are mutually engaged in working; they each hold responsibility for developing the community and have certain resources to implement various practices and routines. Communities of practice differ from other communities or groups because they demand common engagement, shared knowledge and shared methods.

According to Wenger (1998, pp. 51-55), action in communities of practice also involves the negotiation of meanings and reification. The negotiation of meanings describes the process during which the community members try to reach a common understanding. Reification in this process means that an abstract object gradually becomes concrete. Reification binds together the common language and meanings, even connecting an abstract phenomenon to an object; it is not only naming, but also thinking. The negotiation of meaning and reification form a duo that cannot be separated (Wenger, 1998, pp. 51-55). Participation must be based on the strong competence and cooperation of both partners through mutual trust in an evolving partnership process. Partnership can be characterised by the win-win principle, meaning that all partners benefit from jointly accomplishing work. The role of the other person in a partnership is to provide feedback and jointly steer community functions (Nonaka \& Konno, 1998).

Community knowledge is constructed through action, in which some of the ideas and thoughts (conceptual artefacts such as theories, models, problems and plans) are generated by the community. Learning in a community offers invisible and immaterial, yet real and useful situations for learning (Bereiter, 2002; Bereiter \& 
Scardamalia, 1993). The development of teachers' expertise as a community process develops expert communities rather than individual experts in specific fields (see e.g. Bereiter, 2002; Bereiter \& Scardamalia, 1993). When describing social situations, Goffman (1974, pp. 123-125) applied the metaphor of drama to show how social situations demand people act in certain roles, helping to construct frames of life. Thus, Goffman's (1974, p. 563) frame analysis provides an understanding of how to make a broad interpretation of face-to-face situations (Hacking, 2004, p. 278).

\section{Methods}

This study aims to provide a wider picture of students' frames of meaningful learning in andragogical, university-based teacher education programmes. It involves a metasynthesis of articles reporting current research studies on this topic. Metasynthesis seeks to develop new knowledge based on existing qualitative research with the purpose of building a new or fuller understanding of a phenomenon, or possibly the development of a new theory (Aspfors \& Fransson, 2015; Thorne et al., 2002). According to Schreiber, Crooks and Stern (1997), 'It is the bringing together and breaking down of findings, examining them, discovering the essential features, and, in

some way, combining phenomena into a transformed whole'. The product of qualitative metasynthesis is always an integration of research findings, as opposed to a comparison of them (Sandelowski \& Barroso, 2007, p. 199). It may also provide a detailed description of a phenomenon and identify its central features or core concepts (Timulak, 2007).

Metasynthesis is an integration, which is more than simply the sum of its parts. It offers novel interpretations on findings that are the results of interpretative transformations (Sandelowski \& Barroso, 2007, p. 18). Compared to a meta-analysis, the sample size used for metasynthesis is small. As a result, researchers, guided by 
approaches that help avoid bias (Sandelowski, Voils, \& Barroso, 2007), can treat each study with more focused attention, allowing each one to stand as a distinct part of the research (Sandelowski, Docherty, \& Emden, 1997). This metasynthesis involves the synthesis of qualitative findings and results in a comprehensive analysis of phenomena, which makes it a descriptive metasynthesis (Schreiber et al., 1997). We focus on using qualitative methods to integrate qualitative results from prior qualitative studies in a variety of fields.

\section{Implementation of metasynthesis}

Based on previously published descriptions of the process, we conducted this metasynthesis in the following steps: selecting an appropriate research aim and focus, setting inclusion and exclusion criteria, identifying and retrieving qualitative research reports, assessing the quality of the studies, determining the analytic technique, and synthesising and presenting findings across the studies (see Erwin, Brotherson \& Summers, 2011; Hoon, 2013; Noblit \& Hare, 1988; Salter, Hellings, Foley, \& Teasell, 2008; Walsh \& Downe, 2005).

Two different ways of locating studies for the metasynthesis were used at first: keyword search and expert suggestion. To begin, the database ERIC ProQuest was searched using keyword search techniques. They were 'teacher education' and 'andragogy'. Because of the inadequate search returns from these few keywords, terms branching out from the main topic were added, including 'adult education', 'teacher students', 'andragogic', 'andragogical' and 'meaningful learning'. We also sought original studies, which were andragogical and made in university-based teacher education contexts, were reported in English and were peer-reviewed. Any articles published after $31^{\text {st }}$ December in 2008 with these inclusion criteria were included in the metasynthesis. 
The total number of identified studies was 17 . We screened independently at each step of the screening process with consistent consensus. We rejected six studies after a title and abstract screen, therefore the number of studies chosen for the systematic review was 11 (see Figure 1). After full article reviews, five were chosen as relevant for study inclusion in terms of quality by using the Critical Appraisal Skills Programme (CASP). Checklist for qualitative research (CASP, 2017). Each article had to score not less than half the points in CASP critical appraisal in order to be included into the final analysis of the systematic review. This cut-off point was set to guarantee the quality of the interpretation of the systematic review. As a result, two articles out of five were excluded, because they scored only 3/10 points in the CASP critical appraisal. The conclusion of the CASP (10/10) qualitative evaluation was that three cases evinced sufficient quality to be included in this study.

\section{Insert Figure 1 here}

The three original studies selected were extracted by publication reference, purpose, participants, methodology (study design, data collection and data analysis), and summary of findings (Munn et. al 2014) (see Table 1). This methodology allows for the clarification of concepts and patterns, and results in the refinement of existing states of knowledge and emergent operational models and theories (Sherwood, 1999).

The data of all three primary studies were interviews and/or written reflective texts, where teacher students told or wrote about their meaningful learning experiences during the teacher education programmes. The studies differed in terms of research questions, analytic method (phenomenography or Glaserian grounded theory), major subject and prospective education sector of the aspirant-teacher participants. Definitions of dimensions, categories and themes in the primary studies (see Table 1) were used as 
data for the metasynthesis (Finfgeld, 2003).

\section{Insert Table 1 here}

The analytic device for creating this descriptive metasynthesis was constant comparison analysis. According to Finfgeld-Connett (2010), using constant comparison analysis to triangulate across studies with different qualitative methodologies improves the transferability of the findings of the metasynthesis. At the beginning of the analysis we worked interactively and listed the reported categories and themes across the three primary studies. We then progressively compared the categories and themes to group together those conveying similar meanings and to identify overarching themes until no new themes could be identified. As the analysis deepened, the emerging subthemes began to form a systematic construction in which the subthemes were embedded in broader main themes (see Table 2). Finally, the main themes formed the coherent frames of teacher students' meaningful learning inside each other (see Figure 2). The differences of the data appeared in the diversity of the subthemes and in the dualistic nature of the two out of three frames of teacher students' meaningful learning.

\section{Insert Table 2 here}

\section{Results}

On review of the compiled lists of themes and categories, it became apparent that the participants of the primary studies had voiced many similar experiences of meaningful learning. Through independent and interactive readings of the data and conducting the analysis, we identified three different frames of teacher students' meaningful learning, which we shall henceforth call learning worlds. These learning worlds provided frames 
for adult students to make sense of their meaningful experiences of learning during their teacher education programmes. In the following subsections, we summarise the main findings from the metasynthesis with some empirical extracts. We begin by presenting findings relating to the first learning world, professional awakening. Next, we describe the second learning world, transformative community in which the differences of the findings can be seen in its dualistic nature. Finally, we explain the findings of the third learning world, agency in society, which is also dualistic in nature. The learning worlds, the subthemes and main themes are presented in Table 2.

We refer without mention to all three studies if a finding was relevant to all of the studies. If a finding was relevant to only one or two studies, these are referenced as (1), (2) or (3) (see Table 1).

\section{The first learning world: professional awakening}

The first learning world, the professional awakening, consists of three categories: egocentric learner, expanding professionalism and responsibility for self-development.

\section{Egocentric learner}

The first category, the egocentric learner, is the me as a learner. Adult students work hard to achieve the ability for self-regulated learning, even if most of the teacher students first have to learn a different kind of approach to learning than what they had learned in their earlier studies. The autonomy given by educators challenges, encourages and even demands the students also study self-directly because no ready answers are given to them, contrary to their expectations. This awakens confusion and both positive and negative feelings, which can be seen as catalysts for the learning processes, as indicated in an experienced teacher student's text:

The benefits of the training have been kind of indirect, and so not quite what I had expected or originally set out to for. This new teacherhood that has broken 
into my way of thinking will continue living beyond this training and so is more than worth its weight in gold. (2, p. 3345)

The educators must help adult students find their own way to learn and achieve selfregulation by encouraging them to be critical learners, asking questions and guiding them to plan their own learning goals independently. The critical reflection on experiences results in self-analysis as a learner. It also awakens students to the education programme's possibilities for learning in the direction of one's own learning goals. Assessment of, and critical reflection on, the educational principles, content and teaching methods of the programme strengthen adult students' feeling of becoming selfregulated and critical learners.

\section{Expanding professionalism}

Students' expanding professionalism is the second category of the first learning world. It appears as a changing orientation to learning - from egocentric individualism to networking expertise. Concerns and critical points related to one's professional learning capability and uncertainty about one's role and status in the learning group arouse feelings of otherness, which in turn guide students' need to be more involved in collaboration with peer students and to get to know one another better. Interest and involvement in communicative learning activities, including shared expertise, arise in peer groups. An investigative orientation toward study is inspired by confronting the unknown in the professional self and by consensual validation of teaching ideas in group reflection. One teacher student described this as follows:

...we had deep discussions. We even widened our perspectives. I think meetings like this are very useful for our development. You have to argue, but also listen to others' opinions. Oh, I hope to be able to have these kinds of reflective 'expert' meetings in my work community at school. $(1$, p. 8) 
Professional self-expression also develops, and professional perspectives widen. Adult students' need to collaborate in studies, in work and in everyday life becomes part of their professional intent. Moving from an egocentric performer to an autonomous professional collaborator is an emotive pathway for adult students.

\section{Responsibility for self-development}

The third category of the first learning world is responsibility for self-development. Talk of increasing self-understanding and the reconstruction of oneself as a learner, as a professional and even as a human being is a consistent feature in primary studies. Reflective self-analysis after face-to-face learning periods and peer group discussions help the students confront the unknown in themselves as learners and develop a stronger consciousness of themselves as teachers. The younger students strengthen their professional identity, and the more experienced students gain the courage to break their teaching routines. Moreover, the normatively charged perspective of 'teaching right' changes into innovative ideas, ethical reflection and the perspective of 'teaching well' and being a 'good' teacher (1). Epistemological contradictions in teacher students' concepts of knowledge and learning change because of the increasing understanding that several equally practical and useful methods and paths exist for achieving the aims of 'good' teaching.

\section{The second learning world: transformative community}

In the second learning world, transformative community, adult students experience how they are members of learning communities. They feel responsible for creating a student community, developing learning and obtaining resources to carry out teaching practice at school and in other communities. Community consists of two categories: dialogic participation and local educational reification. 


\section{Dialogic participation}

Under dialogic participation, there are two subcategories of adult students' meaningful learning. The first subcategory describes how teacher students participate in the dialogic learning community. Adult students' participation in the dialogic learning community stimulates collective reflection on their own professionalism. For some, traditional family roles are also subjected to critical reflection $(1,2)$. A shared, safe learning atmosphere is considered important, as others can be seen as mirrors in the learning community. For others, teaching together and analysing together their teaching and how they develop themselves as teacher-researchers and experts is rewarding (3). The discussion may be multi-voiced. Unconscious beliefs, habits and tacit knowledge concerning teaching become in reflective group discussions conscious, which cause dissonant emotions. Participants across the studies spoke of an expedition to the professional self. The expedition may be perilous but not unwelcome. For example, one teacher student wrote: 'You need courage to step into the unknown and challenge yourself in peer discussion groups. But it can help you to gain a totally new sense of meaning' (1, p. 9). It is similar to professional polyphonic dialogue, in which adult students share the responsibility to teach and learn in peer groups. The adult students increase professional interaction, try to find consensus and support other people's learning. They study together and share the results of their examinations. They may feel uncertainty and insecurity when they take part in the teachers' community at school, as one teacher student wrote:

The meaningful things... have been to do the teacher's practicum in a real high school and the evaluation conversations after that in my peer group... These have been spaces for critical reflection: What have I done, why, what have others thought about that? Those situations have strengthened my self-efficacy and developed me. (3, p. 479) 
The other subcategory of dialogic participation describes adult students' way of participating as teacher-researchers in a community. The results show that adult students' interest and willingness to research their own teaching attitudes and habits increases. They take a collaborative, investigative and transformative approach to work. They want to be more conscious about their work and to widen their professional perspectives. As one teacher student explained, 'Teaching is committed to different situations, and my own social learning and participating in teaching is part of it.' $(3, \mathrm{p}$. 479).

\section{Local educational reification}

Negotiating with others is also a part of the learning community activities. The second category of the second learning world is local educational reification, which highlights negotiating in different communities and situations. Local educational reification consists of two subcategories: negotiative learning community and expert knowledge.

Teacher students think of themselves as active parts of a negotiative learning community. They generate critical knowledge in groups and create shared and safe group learning spaces with other teacher colleagues. Effective interaction in groups and the permissive working climate are important in encouraging workplace and management culture. In the negotiative learning community, there are opportunities for co-learning, when the learning community values the students' differences and when teaching methods and educative solutions support learning, as evidenced by an entry in one interview:

The biggest benefit of the course has been the discussions with other students and sharing opinions and listening. This mutual sharing of knowledge has been really important in strengthening my own and our shared professional identity - I've gained emotional 
support from the others' input and from their shared experiences from many different teaching situations. (2, p. 3345)

School administrators appreciate expert knowledge of teaching PE, therapeutic exercise and anatomy. Therefore, students' and teachers' feelings of autonomy, recognition for their expertise and persistence in the job are seen as important in the learning community. The teacher students recognise their expertise in their own subject, but they also want to discuss it with others:

\footnotetext{
I have felt that even short moments chatting with another person about my or his/her experience and work have helped me be conscious of my own habits, routines, practices, choices, values and arguments as a teacher and even as a human being. $(1$, p. 10)
}

\section{The third learning world: agency in society}

Overall, the metasynthesis shows that adult students' feelings of empowerment promote constructive critical and ethical thinking about societal activity and educational policies in society. In this third learning world, dialogic learning extends from the nearby social spheres to institutions and the whole society. Adult students increasingly feel themselves to be active agents and fully authorised experts in the system, but they also want to change the system. The third learning world, agency in society, describes the meaningful learning perceived at the level of students' societal membership. Here, teacher students' learning extends to its largest possible context, society, highlighting their widening professional growth and expertise. The categories of the third learning world are empowered networking and ethical power in education.

\section{Empowered networking}

Empowered networking has two subcategories: becoming an expert in society and widening collaboration. Empowered networking means that while learning, students describe how they are experts in society. Networking is a meaningful way of learning 
for them, and it widens to form other networks and collaboration between organisations. Adult students want to be active participants in society and create new networks. The students share a common language for becoming teachers and experts in society. They believe that they have a common space to develop ways of teaching and thus develop the community together. Talk about becoming empowered during teacher education increases. Some students even want to become active agents and fully authorised experts in the system, as described by one teacher student: 'I have been asked to present teaching ideas and methods for increasing well-being to other teachers in my town. I have a lot of expertise to share in my municipality!' (1, p. 8) The students feel they have the power to affect and even to change society.

Widening collaboration means that students cooperate with different schools and organisations. They widen their societal agency when networking and creating associations. They also seek network partners outside school life, position themselves in relation to surrounding communities and may organise local professional learning and discussion groups $(1,2)$. The teacher students make plans for future cooperation with local colleges. A typical example of this is found in the following learning diary entry: 'I have ... pondered how I could motivate local teachers' mutual exchange of ideas and experiences ... It would be much more than just reading articles and books and chatting with my closest colleagues' $(1$, p. 12).

\section{Ethical power in education}

Ethical power in education consists of three subcategories: the power of expertise, the power of the school system and the power of money, management and policy. With an intensifying image of the self as an expert possessing the ethical power of expertise in general well-being (1), adult students position themselves in relation to work, surrounding communities and their colleges. For some teacher students, the main desire 
concerning society is to discuss (3). For others, the most important desire is to influence, change or exert outright control over educational policy as a deliberate system of principles $(1,2)$. Expanding self-understanding brings about societal awakening and empowerment, which in turn spurs ethical reflection and a desire to broaden the ethical discussion to include more complex issues, such as political and social opinions.

Adult students' opportunities to use power in the school system seem to depend on the quality of the workplace democracy, the hierarchy and management culture, the staff's appreciation of the subject, their feeling of autonomy, recognition of their expertise, the working climate, and most of all, their persistence in the job (1). The norms of the school system are strong, even determining professional outlook and implementation of the curriculum. Their studies improve the students' ability to think critically and inspire speculation on the larger function of schools. The teacher students highlight that the teaching and learning resources, such as the teaching spaces and functioning teaching aids, should be tailored. There should be resources for lecturers, educators and experts. The barriers to and facilitators of students' individual learning should be considered $(1,3)$. The students' learning processes are a very important matter for teachers, as could be seen in one teacher student's learning diary: 'If my pupil has symptoms of obesity and anorexia, how should I help her or him, in the framework of physical exercise, to the right path? What should I allow the children to say, to do and to show?' (1, p. 11)

The power of money, management and policy can be seen as a determinant and a threat, causing a lack of ethical values in decision making, which affects resource allocation and prevents education and professional growth from being equally accessed by everyone. The criticism of economic and social problems in society, and a desire to 
question and solve current problems becomes evident (2). It is exemplified in the following student's written reflections: 'Good that some do have courage, faith and hope in the fight against market forces and values saturated with competition in our society...I want to share this faith and hope with pedagogical love:)' (2, p. 3343)

\section{Insert Figure 2 here}

\section{Discussion and conclusion}

This study aimed to provide a wider picture of the frames of adult students' meaningful learning in andragogical teacher education contexts. The results of this study found that the frames, learning worlds, are co-constructed objects among adult students that represent existing meanings in a group during the whole study period (see also Bannister, 2015). The three primary studies offered different methodological perspectives and perspectives from students on the phenomenon under investigation. The results show that the three learning worlds form a common system, which widens from professional awakening to transformative community and agency in society (Figure 2). The community and society as learning worlds are dichotomous in nature, so adult students' membership in a community demands both participation and negotiation. In society, adult students need to be both empowered and to exert their ethical power.

Professional awakening was a meaningful inner learning world for adult students during their two-year studies. The results show how adult students' critical reflection on fundamental questions relative to their personal and professional identity and professionalism seem to contribute greatly to building an understanding of themselves as egocentric learners who expand their professionalism and feel a strong sense of responsibility for self-development. We agree with Kelchtermans' (2009) notion of the self as an individual product at a certain moment and as a process of 
making sense of one's experiences and their impact on the self. Our research demonstrates how teacher students' self-understanding develops and is reconstructed in interactions with others (see also Arvaja, 2016; Gossman \& Horder, 2016; Uitto, Kaunisto, Kelchtermans, \& Estola, 2016).

The transformative community is a two-sided learning world, a place where adult students participate actively and negotiate their positions in the community. In this study, the social activities of collaboration and networking form learning communities which act as sociocultural environments and even as communities of practice, like spaces for students to learn (Skaniakos \& Piirainen, 2019; Tynjälä, 2013). Bannister (2015) found similar results in how teachers' learning in teams form the duality of participation and reification (Wenger, 1998). The teachers see themselves as sociocultural agents who can affect the institution of education in the local area and in society (e.g. Säljö, 2006, pp. 206-208). They also build alliances with which to develop the educational system (Brookfield, 2015, pp. 254-256).

Our results show that empowered networking and ethical power in education link the students to society, the third learning world. Empowered adult students identify themselves as experts in well-being with a strong ethical conscience. This finding is in line with recent studies concerning the significance of increasing self-knowledge in activating teachers' ethical thinking and action (Fernández-Balboa, 2009), and in how ethicality gives rise to feelings of power (Flint, Zisook, \& Fischer, 2011). However, adult students also resist the external norms of the educational system (Arvaja, 2016) and want to develop it and have an impact on society (cf. Lanas \& Kelchtermans, 2015). The contradiction between the adult students' voice and the authoritative voice of the educational system may result in struggles between humanistic and managerialistic 
ideologies (Arvaja, 2016; Zembylas, 2003), which offer a possibility for progressive movements in terms of the students' self-construction and future work plans.

In this study, we relied on Wenger's (1998) social concept of learning, in which identity is defined through learning, experiencing, doing and belonging. Our results clearly indicate how the importance of experience and participation in communities deepen students' understanding of themselves as professionals and human beings. This supports Wenger's (1998, p. 227) assertion that learning is fundamentally experiential and social. The data also suggest, in line with other recent studies (Timoštšuk \& Ugaste, 2010; Uitto et al., 2016), that becoming a teacher is a highly emotional experience. Teacher students need the community and society to support them and provide space for negotiation on development (Brookfield, 2015, pp. 239-256). Epistemological contradictions in adult students' conceptualisation of knowledge and learning in peer groups, as well as confrontation with the unknown within the professional self in group reflection, may awaken their emotions. To be able to go beyond the experiences and emotions, we recommend that adult education institutes adopt educational approaches that facilitate collaboration, problem solving, investigative activities, written and oral communication skills and critical reflection on the emotions aroused (Andrade, 2016).

Certainly, there are limitations to this type of study. As qualitative findings based on small samples, they cannot always be generalized to other contexts. However, qualitative metasynthesis is suitable for individual qualitative studies, which do not use a conceptual framework as a system for organizing data (Timulak 2009). Then again, the primary data of this qualitative study were the findings of researcher-generated interpretations, which also included quotations collected in primary studies (Sandelowski \& Barroso 2007, p. 248). The results of this metasynthesis were also 
discussed with other research results. This kind of triangulation enhanced the trustworthiness of the study (Timulak 2009).

The results show that when opportunities for the empowerment of teacher students are enabled, teacher students actively focus their learning and participation on widening their learning worlds. By combining practice and theory in andragogical teacher education and by emphasising the importance of collaboration and networking for the renewal of teacher education programmes (Peck, Calluicci, Sloan, \& Lippincott, 2009; Vähäsantanen, 2015), the teacher students may become empowered, active participants and agents in society.

This article created new knowledge about adult teacher students' learning worlds, a framework which can be used in planning curricula and programmes. Future research using participants with various backgrounds in a similar educational context could provide interesting results on the relevance of the learning worlds.

\section{References}

Aarto-Pesonen, L. (2013). "Tää koulutus ei oo tehnyt musta pelkkää jumppamaikkaa". Substantiivinen teoria aikuisoppijan ammatillisen kasvun holistisesta prosessista liikunnanopettajakoulutuksessa. ["The training made me more than just a PE teacher". A substantive theory about the holistic process of adult learnersprofessional development in physical education teacher education] (Doctoral dissertation). University of Jyväskylä, Finland.

Aarto-Pesonen, L., \& Tynjälä, P. (2017a). Dimensions of professional growth in workrelated teacher education. Australian Journal of Teacher Education, 42(1), 1. https://doi.org/10.14221/ajte.2017v42n1.1

Aarto-Pesonen, L. \& Tynjälä P. (2017b). The core of professional growth in workrelated teacher education. The Qualitative Report, 22(12), 3334-3354. 
Afshan, H. (2016). Cultural scripts resist reforms in teacher education. Journal of Education and Practice, 7(18), 26-31. Retrieved from http://files.eric.ed.gov/fulltext/EJ1105838.pdf

American Psychological Association Taskforce. (2014). Assessing and evaluating teacher preparation programs: APA taskforce report. Retrieved from http://www.apa.org/ed/schools/cpse/teacher-preparation-programs.pdf

Andrade, M. S. (2016). Curricular elements for learner success $-21^{\text {st }}$ century skills." Journal of Education and Training Studies, 2, 143-149. https://doi.org/10.11114/jets.v4i8.1743

Aragon, S. (2016). Teacher shortages: What we know. Education Commission of the States. Retrieved from: https://files.eric.ed.gov/fulltext/ED565893.pdf

Arvaja, M. (2016). Building teacher identity through the process of positioning. Teaching and Teacher Education, 59, 392-402. https://doi.org/10.1016/j.tate.2016.07.024

Aspfors, J. \& Fransson, G. (2015). Research on mentor education for mentors of newly qualified teachers: A qualitative meta-synthesis. Teaching and Teacher Education, 48, 75-86. https://doi.org/10.1016/j.tate.2015.02.004

Ausubel, D. P., \& Fitzgerald, D. (1961). Meaningful learning and retention: Intrapersonal cognitive variables. Review of Educational Research, 31(5), 500-510. https://doi.org/10.3102/00346543031005500

Avalos, B. (2011). Teacher professional growth in teaching and teacher education over ten years. Teaching and Teacher Education, 27, 10-20. https://doi.org/10.1016/j.tate.2010.08.007

Bannister, N. A. (2015). Reframing practice: Teacher learning through interactions in a collaborative group. Journal of the Learning Sciences, 24, 347-372. https://doi.org/10.1080/10508406.2014.999196

Bereiter, C. (2002). Education and mind in the knowledge age. Mahwah, NJ: Lowrence Erlbaum associates.

Bereiter, C., \& Scardamalia, M. (1993). Surpassing ourselves. An inquiry into the nature and implications of expertise. Chicago, IL: Open Court.

Billett, S. (2009). Conceptualizing learning experiences: Contributions and mediations of the social, personal, and brute. Mind, Culture and Activity, 16(1), 32-47. https://doi.org/10.1080/10749030802477317 
Broadbent, C., \& Brady, J. (2013). Leading change in teacher education in Australia through university-school partnerships. The European Journal of Social \& Behavioral Science, 4, 687-703. https://doi.org/10.15405/FutureAcademy/ejsbs(2301-2218).2012.4.4

Brookfield, S. D. (2015). The skillful teacher: On technique, trust, and responsiveness in the classroom (3rd ed.). San Francisco, CA: Jossey-Bass.

Bruner, J. (1990). Acts of learning. Cambridge, MA: Harvard University Press.

Cochran-Smith, M., \& Power, C. (2010). New directions for teacher preparation. Educational Leadership, 67(8), 6-13.

Critical Appraisal Skills Programme (CASP). (2017). CASP the checklist for qualitative research. Retrieved from https://casp-uk.net/casp-tools-checklists/

Daves, D. P., \& Roberts, J. G. (2010). Online teacher education programs: Social connectedness and the learning experience. Journal of Instructional Psychology, 4, 1-9. Retrieved from https://eric.ed.gov/?id=EJ1096997.

Erwin, E. J., Brotherson, M. J., \& Summers, J. A. (2011). Understanding qualitative metasynthesis. Issues and opportunities in early childhood intervention research. Journal of Early Intervention 33(3), 186-200. https://doi.org/10.1177/1053815111425493

European Commission/EACEA/Eurydice, (2018). Teaching Careers in Europe: Access, Progression and Support. Eurydice Report. Luxembourg: Publications Office of the European Union. https://doi.org/10.2797/309510

Fernández-Balboa, J.-M. (2009). Bio-pedagogical self-reflection in PETE:

Reawakening the ethical conscience and purpose in pedagogy and research. Sport, Education and Society, 14, 147-163.

https://doi.org/10.1080/13573320902808981

Finfgeld, D. L. (2003). Meta-synthesis: The state of the art—so far. Qualitative Health Research, 13, 893-904. https://doi.org/10.1177/1049732303253462

Finfgeld-Connett, D. (2010). Generalizability and transferability of meta-synthesis research findings. Journal of Advanced Nursing 66(2), 246-254. https://doi.org/10.1111/j.1365-2648.2009.05250.x 
Flint, A. S., Zisook, K., \& Fisher, T. R. (2011). Not a one-shot deal: Generative professional development among experienced teachers. Teaching and Teacher Education, 27, 1163-1169. https://doi.org/10.1016/j.tate.2011.05.009

Goffman, E. (1974). Frame analysis: An essay on the organization of experience. New York, NY: Harper \& Row.

Gossman, P., \& Horder, S. (2016). Effective teacher? Student self-evaluation of development and progress on a teacher education programme. Journal of Further and Higher Education, 40, 447-465. https://doi.org/10.1080/0309877X.2014.984595

Green, M. M. (2016). Preparing pre-service teachers for professional engagement through place/community pedagogies and partnerships. Australian Journal of Teacher Education, 41(11), 44-60. https://doi.org/10.14221/ajte.2016v41n11.4

Hacking, I. (2004). Between Michel Foucault and Erving Goffman: Between discourse in the abstract and face-to-face interaction. Economy and Society, 33, 277-302. https://doi.org/10.1080/0308514042000225671

Hakkarainen, P., Saarelainen, T., \& Ruokamo, H. (2007). Towards meaningful learning through digital video supported, case based teaching. Australasian Journal of Educational Technology, 23(1), 87-109. https://doi.org/10.14742/ajet.1275

Hoon, C. (2013). Meta-synthesis of qualitative case studies. An approach to theory building. Organizational Research Methods, 16(4), 522-556. https://doi.org/10.1177/1094428113484969

Hussain, I. (2013). A study of learners' reflection on andragogical skills of distance education tutors. International Journal of Instruction, 1(1), 123-137.

Jarvis, P. (1987). Meaningful and meaningless experience: Towards an analysis of learning from life. Adult Education Quarterly, 37(3), 164-172. https://doi.org/10.1177/0001848187037003004

Kehrwald, B. A., \& McCallum, F. (2015). Degrees of change: Understanding academics experiences with a shift to flexible technology-enhanced learning in initial teacher education. Australian Journal of Teacher Education, 40(7), 43-56. https://doi.org/10.14221/ajte.2015v40n7.4

Kelchtermans, G. (2009). Who I am in how I teach is the message: Self-understanding, vulnerability and reflection. Teachers and Teaching: Theory and Practice, 15, 257-272. https://doi.org/10.1080/13540600902875332

Keskitalo, T., Pyykkö, E., \& Ruokamo, H. (2011). Exploring the meaningful learning of 
students in second life. Educational Technology \&Society, 14(1), 16-26.

Knowles, M. S. (1984). The adult learner: A neglected species. Houston, TE: Gulf.

Korthagen, F. A. J. (2010). How teacher education can make a difference. Journal of Education for Teaching, 36, 407-423. https://doi.org/10.1080/02607476.2010.513854

Korthagen, F., Loughran, J., \& Russell, T. (2006). Developing fundamental principles for teacher education programs and practices. Teaching and Teacher Education, 22, 1020-1041. https://doi.org/10.1016/j.tate.2006.04.022

Kostiainen, E., Ukskoski, T., Ruohotie-Lyhty, M., Kauppinen, M., Kainulainen, J., \& Mäkinen T. (2018). Meaningful learning in teacher education. Teaching and Teacher Education, 71, 66-77. https://doi.org/10.1016/j.tate.2017.12.009

Lanas, M., \& Kelchtermans, G. (2015). This has more to do with who I am than with my skills - Student teacher subjectification in Finnish teacher education. Teaching and Teacher Education, 47, 22-29. https://doi.org/10.1016/j.tate.2014.12.002

Lindeman, E. (1926/1961). The meaning of adult education. New York, NY: New Republic.

Merriam, S. B., \& Clark, M. C. (1993). Learning from life experience: What makes it significant? International Journal of Lifelong Education, 12(2), 129-138. https://doi.org/10.1080/0260137930120205

Mezirow, J. (1991). Transformative Dimensions of Adult Learning. San Francisco, CA: Jossey-Bass.

Moher, D., Liberati, A., Tetzlaff, J, \& Altman, D.G. (2009). Preferred reporting items for systematic reviews and meta-analyses: The PRISMA Statement. PLoS Med 6(7), e1000097. https://doi.org/10.1371/journal.pmed.1000097

Munn, C.T., \& Aromataris, E. (2014). Data extraction and synthesis. The step following study selection in a systematic review. American. Journal of Nursing 114(7), 49-54. https://doi.org/10.1097/01.NAJ.0000451683.66447.89

Noblit, G. W., Hare, R. D. (Eds.). (1988). Meta-ethnography: synthesizing qualitative studies. Newbury Park, CA: Sage Publications.

Nonaka, I., \& Konno, N. (1998). The concept of "Ba": Building a foundation for knowledge creation. California Management Review, 40(3), 40-54. https://doi.org/10.2307/41165942 
Novak, J. D. (2002). Meaningful learning: The essential factor for conceptual change in limited or inappropriate propositional hierarchies leading to empowerment of learners. Science Education, 86(4), 548-571. https://doi.org/10.1002/sce.10032

Okukawa, H. (2008). If your learning experience is meaningful for you, how have you been constructing that meaning? A study of adult learners in Bangkok. International Forum of Teaching and Studies, 4(1), 46-61.

Peck, C., Calluicci, C., Sloan, T., \& Lippincott, A. (2009). Organizational learning and programme renewal in teacher education. A sociocultural theory of learning, innovation and change. Educational Research Review, 4(1), 16-25. https://doi.org/10.1016/j.edurev.2008.06.001

Piirainen, A. (2014). The peer groups bridging the disciplines and social contexts in higher education. In B. Käpplinger, N. Lichte, E. Haberzeth \& C. Kulmus (Eds.), Changing configurations of adult education in transitional times (pp. 473-484). Berlin: Humboldt-Universität Press.

Rachal, J. (2015). Reflections on the Lindeman legacy. Journal of Lifelong learning, 24, $1-6$.

Rismiyanto, S.M., \& Mujiyanto, J. (2018). The effectiveness of andragogically oriented teaching method to improve the male students' achievement of teaching practice. English Language Teaching, 11(2), 113-121.

Salter, K.; Hellings, C., Foley, N., \& Teasell, R. (2008). The experience of living with stroke: A qualitative meta-synthesis. Journal of Rehabilitation Medicine 40(8), 595-602. https://doi.org/10.2340/16501977-0238

Sandelowski, M, \& Barroso, J. (2007). Handbook for Synthesizing Qualitative Research. New York, NY: Springer.

Sandelowski, M., Docherty, S., \& Emden, C. (1997). Focus on Qualitative Methods Qualitative Metasynthesis: Issues and Techniques. Research in Nursing and Health, 20(4), 365-371. https://doi.org/10.1002/(SICI)1098240X(199708)20:4<365::AID-NUR9>3.0.CO;2-E

Sandelowski, M., Voils, C. I., \& Barroso, J. (2007). Comparability work and the management of difference in research synthesis studies. Social Science and Medicine, 64(1), 236-247.

Savicevic, D. (2008). Convergence or divergence of ideas on andragogy in different countries. International Journal of Lifelong Education, 27, 361-378. https://doi.org/10.1080/02601370802051504 
Schreiber, R., Crooks, D., \& Stern, P. N. (1997). Qualitative meta-analysis. In J. M. Morse (Ed.), Completing a qualitative project: Details and dialogue (pp. 311326). Thousand Oaks, CA: Sage.

Sherwood, G. D. (1999). Meta-synthesis: Merging qualitative studies to develop nursing knowledge. International Journal for Human Caring, 3, 37-42.

Skaniakos, T., \& Piirainen, A. (2019). The meaning of peer group mentoring in teacher education in the university context. International Journal of Evicence Based Coaching and Mentoring, 17(1).

Sobolev, A.B. (2016). The teacher education development program: New challenges. Russian Education \& Society, 58(2), 121-132. https://doi.org/10.1080/10609393.2016.1214490

Säljö, R. (2006). Lärande i praktiken, ett sociokulturellt perspective. Stockholm: Nordstedts Akademiska Förlag.

Teacher Education Forum. (2016). Teacher education development programme. Ministry of Education and Culture, Finland. Retrieved from https://minedu.fi/documents/1410845/4183002/Teacher\%20Education\%20Devel opment\%20Programme\%202016/19ecada4-ca45-4729-8797-0f2741486897

Teacher Education Ministerial Advisory Group. (2014). Action now: Classroom ready teachers. Retrieved from https://docs.education.gov.au/system/files/doc/other/action now classroom rea dy teachers print.pdf

Thorne, S., Paterson, B., Acorn, S., Canam, C., Joachim, G., \& Jillings, C. (2002). Chronic illness experience: Insights from a meta-study. Qualitative Health Research, 12(4), 437-452. https://doi.org/10.1177/104973202129120007

Timoštšuk , I., \& Ugaste, A. (2010). Student teachers professional identity. Teaching and Teacher Education, 26, 1563-1570. https://doi.org/10.1016/j.tate.2010.06.008

Timulak, L. (2007). Identifying core categories of client-identified impact of helpful events in psychotherapy: A qualitative meta-analysis. Psychotherapy Research, 17, 305-314. https://doi.org/10.1080/10503300600608116 
Timulak, L. (2009). Meta-analysis of qualitative studies: A tool for reviewing qualitative research findings in psychotherapy. Psychotherapy Research, 19(45), 591-600, https://doi.org/10.1080/10503300802477989

Tsai, C.-W., Shen, P.-D., \& Chiang, Y.-C. (2013). Research trends in meaningful learning research on e-learning and online education environments: A review of studies published in SSCI-indexed journals from 2003 to 2012. British Journal of Educational Technology, 44(6), E179-184. https://doi.org/10.1111/bjet.12035

Tynjälä, P. (2013). Toward a 3-P model of workplace learning: A literature review. Vocations and Learning, 6, 11-36. https://doi.org/10.1007/s12186-012-9091-z

Uitto, M., Kaunisto, S-L., Kelchtermans, G., \& Estola, E. (2016). Peer group as a meeting place: Reconstructions of teachers' self-understanding and the presence of vulnerability. International Journal of Educational Research, 75, 7-16. https://doi.org/10.1016/j.ijer.2015.10.004

Valli, R., Valli, P., \& Lähdesmäki, S. (2017). Meaningful learning experiences in the Finnish teacher education. Asian Journal of Education and e-Learning, 5(2), 2735. https://doi.org/10.24203/ajeel.v5i2.4471

Vygotsky, L. S. (1934/1962). Thought and language. Cambridge, MA: MIT Press. https://doi.org/10.1037/11193-000

Vähäsantanen, K. (2015). Professional agency in the stream of change: Understanding educational change and teachers' professional identities. Teaching and Teacher Education, 47, 1-12. https://doi.org/10.1016/j.tate.2014.11.006

Walsh, D., \& Downe, S. (2005). Meta-synthesis method for qualitative research: A literature review. Journal of Advanced Nursing 50(2), 204-211. https://doi.org/10.1111/j.1365-2648.2005.03380.x

Wenger, E. (1998). Communities of practice: Learning, meaning and identity. Cambridge University Press. https://doi.org/10.1017/CBO9780511803932

Wolfe, P. (2006). The role of meaning and emotion in learning. New Directions for Adult and Continuing Education, 2006(110), 35-41. https://doi.org/10.1002/ace.217

Zembylas, M. (2003). Emotions and teacher identity: A poststructural perspective. Teachers and Teaching, 9, 213-238. https://doi.org/10.1080/13540600309378 